\title{
Performance Evaluation of a Two-Phase Anaerobic Digestion Process of Synthetic Domestic
}

\section{Wastewater at Ambient Temperature}

L. GUERRERO ${ }^{1}$, S. MONTALVO ${ }^{2}$, E. CORONADO ${ }^{1}$, R. CHAMY $^{3}$, P. POIRRIER $^{3}$, D. CRUTCHIK $^{1}$, E. SÁNCHEZ ${ }^{4}$, M.A. DE LA RUBIA ${ }^{5}$ and R. BORJA ${ }^{5 *}$

${ }^{1}$ Department of Chemical, Biotechnological and Environmental Processes, Federico Santa María Technical University, Ave. España 1680, Valparaiso, Chile.

${ }^{2}$ Department of Chemical Engineering, Santiago de Chile University, Ave. Lib. Bernardo O’Higgins 3363, Santiago de Chile, Chile.

${ }^{3}$ Biochemical Engineering School, Catholic University of Valparaiso, Ave. Brasil 2950, Valparaiso, Chile.

${ }^{4}$ Centro de Ciencias Medioambientales (CSIC), C/ Serrano 115-duplicado, 28006-Madrid, Spain. ${ }^{5}$ Instituto de la Grasa (CSIC), Avda. Padre García Tejero, 4, 41012-Sevilla, Spain.

\section{ABSTRACT}

A two-phase anaerobic digestion process of synthetic domestic wastewater was studied at ambient temperature in mild to cold climates. The hydrolytic stage was carried out in a continuous stirred tank reactor with an effective volume of $1.2 \mathrm{~L}$. The hydrolytic reactor operated at hydraulic retention times (HRTs) in the range of 1.3 to $2.7 \mathrm{~h}$, which allowed for optimum HRT to be obtained in order to achieve a maximum amount of soluble COD. For the methanogenic stage, an up-flow anaerobic filter with a volume of $1.35 \mathrm{~L}$ and corrugated

* Address correspondence to R. Borja, Instituto de la Grasa (C.S.I.C.), Avda. Padre García Tejero, 4, 41012-Sevilla, Spain (Phone: +34 95 4689654, Fax: +34 95 4691262; E-mail: rborja@cica.es) 
plastic rings as biomass immobilization support were used. During the investigation, the ambient temperature ranged between $21^{\circ} \mathrm{C}$ and $24{ }^{\circ} \mathrm{C}$. Synthetic domestic wastewater with a COD of $700 \mathrm{mg} / \mathrm{L}$ was used as substrate. The study was performed at total organic loading rates $\left(\mathrm{OLR}_{\mathrm{T}}\right)$ of 2.0-4.3 $\mathrm{g} \mathrm{COD} / \mathrm{L} \cdot \mathrm{d}$, with a global HRT (including both hydrolytic and methanogenic stages) of 2.8-5.8 hours. A maximum percentage of organic matter removed of $88 \%$ was achieved at a global HRT of 5.8 hours. Under these operating conditions, the production of biogas was $97 \%$ higher than that obtained in the one-phase anaerobic digestion process. Additionally, the kinetics involved in the hydrolytic stage was determined using the Contois kinetic model, which adequately predicted the experimental results.

Keywords: Two-phase anaerobic digestion, hydrolytic stage, methanogenic stage, kinetics, synthetic domestic wastewater.

\section{INTRODUCTION}

The anaerobic digestion process is an excellent and attractive alternative for the reduction of the organic matter concentration of wastes and wastewaters and has been previously applied for treatment of a number of substrates such as various complex feedstocks including municipal wastewater sludges, chemical and agricultural industry wastewaters, etc. ${ }^{[1]}$ Compared to other biological wastewater treatment processes, anaerobic digestion offers significant advantages, such as lower sludge production, the generation of methane gas of high calorific value, lower energy consumption, lower space requirements and lower overall costs. ${ }^{[2]}$ In conventional applications, the hydrolytic, acid-forming and methanogenic microorganisms are kept together in a single reactor system. There is a delicate balance between these two groups of 
microorganisms, because they differ greatly in terms of physiology, nutritional needs, growth kinetics and sensitivity to environmental conditions. Problems encountered with stability and control in conventional one-stage reactors have led researchers to new alternatives. ${ }^{[2]}$ Therefore, providing the most appropriate environmental and operational conditions for each microbial community in two-reactor systems which are physically separated consequently has significant outcomes, such as increased overall process efficiency, stability and control, a higher specific activity of methane-formers in the methanogenic reactor, higher organic loading rates and a faster start-up of high-rate systems. ${ }^{[3,4]}$ During the hydrolytic-acidogenic stage, particulate organic matter is firstly hydrolyzed to sugars, fatty acids and aminoacids by extracellular enzymes. These relatively simple compounds are then fermented to short-chain fatty acids, alcohols, carbon dioxide and hydrogen by the acid-forming bacteria. Since the performance of the hydrolytic-acidogenic reactor affects the performance of the subsequent methane reactor, both optimum environmental and operational parameters influencing the hydrolytic-acidogenic digestion should be determined for each waste or substrate in question. ${ }^{[3,5]}$

Among the environmental parameters, $\mathrm{pH}$ and temperature are important factors in two-phase anaerobic treatment. Fang and $\mathrm{Yu}{ }^{[6]}$ studied the influence of temperature and $\mathrm{pH}$ on the acidification stage of wastewater with a high content of gelatin (protein substance) in an up-flow reactor. They concluded that an increase in the temperature caused an insignificant increase in the degree of acidification within the system, but determined that the influence that $\mathrm{pH}$ has on this fermenting stage is much more significant. An increase in $\mathrm{pH}$ from 6.0 to 6.5 caused an increase in the percentage of acidification from $32 \%$ to $72 \%$; a further increase in $\mathrm{pH}$ to 7 produced a decrease in the degree of acidification to $66 \%$. Previously Zoetemeyer et al. ${ }^{[7]}$ studied the influence of $\mathrm{pH}$ on the acidogenesis of a simple, soluble substrate, glucose, over the range of 4.5 to 7.9 , and recommended a $\mathrm{pH}$ range of 5.7-6.0 for the acid reactor to provide a stable and more favourable substrate for the methane reactor, while Elefsiniotis and Oldham ${ }^{[8]}$ reported that the variation in $\mathrm{pH}$ 
between 4.3 and 5.2 did not affect volatile fatty acids (VFA) production or chemical oxygen demand (COD) solubilization, but higher $\mathrm{pH}$ levels (5.9-6.2) affected both parameters in the acidogenesis of a complex substrate-primary sludge. Variations in higher $\mathrm{pH}$ levels from 6.0 to 8.0 were reported to be affecting the dominant microbial population in the acid reactor. ${ }^{[9]}$ The effects of hydraulic retention time (HRT) on anaerobic acidogenesis have been investigated earlier. ${ }^{[2]}$ However, contradictory results have been reported. HRT was found to affect the performance of the acid reactor by some researchers. ${ }^{[3]}$ On the other hand, no significant influence of HRT was observed on anaerobic acidogenesis in other studies. ${ }^{[10]}$ Borja et al. ${ }^{[1]}$ studied the influence of the HRT on the acidogenic fermentation of wastes derived from the production of olive oil, determining the optimum values for this type of substrate. The criteria used to determine the optimum HRT not only depended on an elevated percentage of hydrolysis, but also on the type of volatile fatty acid that was obtained. They reported that long chain volatile fatty acids have higher formation velocities than that of acetic acid. Therefore, an elevated percentage of these acids is obtained at very low HRTs. They determined that the reduction in the HRT favored the hydrolytic process, hindering the growth and proliferation of methanogenic microorganisms. Based on these studies, the optimization of the hydrolytic stage should be focused on achieving the solubility of the highest possible amount of particulate or organic matter in suspension. This implies that the HRT, that allows for the highest value of soluble COD in the effluent of the hydrolytic reactor to be obtained, must be determined.

The majority of the studies carried out up to now have been done with wastewater with high organic matter content. However, few studies were performed with wastewaters with low organic content as is the case of domestic or urban wastewater.

Although the hydrolysis of particulate organic material has been considered the rate-limiting step in anaerobic digestion, some authors have emphasized that the hydrolytic process still remains the least defined step ${ }^{[11]}$. The cumulative effects of the different processes taking place during 
hydrolysis have traditionally been simplified to a single first-order kinetics for substrate biodegradation ${ }^{[12]}$. However, relatively high hydrolysis rates were reached in anaerobic biodegradability tests with a high inoculum-substrate ratio, ${ }^{[13]}$ showing some degree of dependence of hydrolysis on biomass concentration or activity. Consequently, first order kinetics appears not to be applicable in all circumstances, indicating that an in-depth understanding of the different processes involved is needed to accurately describe hydrolysis.

During hydrolysis the particulate substrates contact the hydrolytic microbial cells and the released enzymes, so that two main phases might be taken into account for a description of the kinetics of hydrolysis. ${ }^{[12]}$ The first phase is a bacterial colonization in which the hydrolytic bacteria cover the surface of the solids. Bacteria on or near the particle surface release enzymes and produce the monomers that are used by the hydrolytic bacteria. The daughter cells fall off into the liquid phase and then try to attach to some new place on a particle surface. Thus, a direct enzymatic reaction as the intermediate step of the total two-phase process may be rather quick in comparison with the stages of bacterial colonization and surface degradation. When an available surface is covered with bacteria, the surface will be degraded at a constant depth per unit of time (second phase).

Microorganisms attached to a particle produce enzymes in the vicinity of this particle and benefit from soluble products released by the enzymatic reaction. It has been recently demonstrated that the Contois model that uses a single parameter to represent saturation of both substrate and biomass is as good at fitting the data as two-phase model. ${ }^{[12]}$

The aim of this work was to study the performance evaluation of a two-phase anaerobic digestion of synthetic domestic wastewater at ambient temperatures $\left(21-24^{\circ} \mathrm{C}\right)$ assessing the influence of HRT and OLR on the overall process. Laboratory-scale continuous stirred tank reactor (CSTR) and upflow filter were used in the hydrolytic-acidogenic and methanogenic stages, respectively. In addition, a kinetic study of the hydrolytic stage based on the Contois model was also carried out following up the degradation of the particulate or insoluble organic matter. 


\section{MATERIALS AND METHODS}

\section{General Scheme of the Two-Phase Anaerobic Digestion Process}

A CSTR reactor was used to carry out the hydrolytic stage, while the methanogenic stage was performed in an up-flow anaerobic filter, which was also used in a previous study of one-stage anaerobic digestion of this substrate. ${ }^{[14]}$ The reactors were operated in series. Because the highest production of acetic acid generally occurs at a $\mathrm{pH}$ of $6.5^{[6]}$, the wastewater was initially fed to the CSTR, the $\mathrm{pH}$ of the feed was regulated and kept at 6.5 by adding $\mathrm{HCl}$ at $36 \%$. The effluent from this reactor was loaded on to a clarifier or settler by gravity, with the purpose of decanting and separating the biomass. After that, the effluent from the settler was fed to the up-flow anaerobic filter, where the methanogenic stage was performed. Since the effluent from the hydrolytic reactor was slightly acidic, sodium bicarbonate was added to the settler to give alkalinity to the anaerobic filter.

The influence of the HRT on the percentage of biodegradation of this substrate in the two-phase anaerobic digestion was assessed. Therefore, in this study the experiments were carried out with different flow-rates that can determine global or total HRTs (HRT of CSTR + HRT of anaerobic filter), similar to those studied in a one-phase anaerobic digestion process. ${ }^{[14]}$

\section{Hydrolytic Reactor}

The hydrolytic reactor consisted of a glass cylindrical reactor $30 \mathrm{~cm}$ high, $25 \mathrm{~cm}$ in internal diameter and with a volume of $1.2 \mathrm{~L}$. The reactor was fed from the top and the discharge of the 
effluent was carried out from the bottom of the lateral wall. The reactor was mixed with a magnetic stirrer that operated at $150 \mathrm{rpm}$ to assure a complete mix.

\section{Settler}

The conical settler or clarifier had a volume of $1.25 \mathrm{~L}$. It had an acrylic top, where the feed is loaded and the effluent unloaded. It also had a mechanism to purge the sludge from the bottom as well as a deflector ( $60 \%$ of the length of the settler) that divided the volume into two sections, making the liquid flow in a $U$ shape.

\section{Anaerobic Filter}

The anaerobic filter used in the methanogenic stage of the two-phase study consisted of an acrylic column with an internal diameter of $8 \mathrm{~cm}$ and $45 \mathrm{~cm}$ high. As support material for the microbial biomass, 330 corrugated plastic rings, with an individual diameter of $1.5 \mathrm{~cm}$ and $1.2 \mathrm{~cm}$ high, were used. The empty volume of the reactor was $1.5 \mathrm{~L}$, while its effective volume was $1.35 \mathrm{~L}$. The biogas production was indirectly measured through the displacement of liquid contained in a Mariotte type bottle. The biogas flowed from the anaerobic filter to the bottle, which contained an alkaline solution of $\mathrm{NaOH}$ at $2.5 \% \mathrm{w} / \mathrm{w}$, with alizarin yellow as a $\mathrm{CO}_{2}$ saturation indicator. The $\mathrm{CO}_{2}$ produced was absorbed into the alkaline solution. Therefore, the volume of the displaced liquid in the Mariotte bottle corresponded to the methane produced, as well as negligible amounts of $\mathrm{H}_{2}$ and $\mathrm{N}_{2}$ gas.

\section{Characteristics of the Wastewater and Inoculum}


During the experiments, synthetic domestic wastewater was used. The composition of the wastewater used is summarized in Table 1 . The main characteristics and features of the synthetic domestic wastewater used are shown in Table 2. This Table also shows the range of values of the typical parameters of a real domestic wastewater reported in the literature for comparison purposes. $[15,16]$

The anaerobic sludge used as an inoculum of the reactors came from a sewage treatment plant that operated at mesophilic temperature. The sludge characteristics were: $69.13 \mathrm{~g} / \mathrm{L}$ of total suspended solids (TSS), $44.00 \mathrm{~g} / \mathrm{L}$ of volatile suspended solids (VSS), $91.23 \mathrm{~g} / \mathrm{L}$ of COD and a specific methanogenic activity (SMA) of $0.5 \mathrm{~g} \mathrm{COD}-\mathrm{CH}_{4} / \mathrm{g} \mathrm{VSS} \cdot \mathrm{d}$.

\section{Chemical Analyses}

The following parameters were determined at the effluents of hydrolytic and methanogenic reactors: total $\mathrm{COD}\left(\mathrm{COD}_{\mathrm{T}}\right)$, soluble $\mathrm{COD}\left(\mathrm{COD}_{\mathrm{S}}\right), \mathrm{pH}$ and VFA. All analyses were carried out according to the recommendations of the Standard Methods for the Examination of Water and Wastewater. ${ }^{[17]}$

\section{The Start-up and Operation of the Reactors}

\section{CSTR reactor}

The CSTR reactor was inoculated with $400 \mathrm{~mL}$ of the above-mentioned inoculum. The rest of the reactor volume was charged with $800 \mathrm{~mL}$ of a nutrient solution made up of glucose $\left(\mathrm{C}_{6} \mathrm{H}_{12} \mathrm{O}_{6}\right)$ as the carbon source, ammonium chloride $\left(\mathrm{NH}_{4} \mathrm{Cl}\right)$ as the nitrogen source and potassium phosphate $\left(\mathrm{KH}_{2} \mathrm{PO}_{4}\right)$ as the phosphorus source, with a $\mathrm{C}: \mathrm{N}: \mathrm{P}$ ratio of $350: 5: 1$. The nutrients were chosen 
taking into account the following criteria: substrate biodegradability and their need for the crucial growth of the microorganisms responsible for the process.

To acclimatize the sludge to the operating conditions, the reactor was initially operated in batch mode. This period of acclimatization lasted approximately 20 days. After this initial acclimatization period, the hydrolytic reactor began to be fed in a continuous mode, and the effluent began to be used as feed for the anaerobic filter, having previously passed through the settler. Four sets of continuous experiments were carried out in the hydrolytic reactor at hydraulic retention times (HRTs) of 2.7, 2.1, 1.5 and $1.3 \mathrm{~h}$. These HRTs corresponded to organic loading rates (OLRs) of the hydrolytic stage of 4.37, 5.63, 7.90 and $9.00 \mathrm{~g} \mathrm{COD} / \mathrm{L} \cdot \mathrm{d}$. The samples were collected and analyzed for at least five consecutive days. The steady-state value of a given parameter was taken as the average of these consecutive measurements for that parameter when the deviations between the observed values were less than $5 \%$ in all cases.

The OLRs applied were gradually increased in order to minimize the transient impact on the reactor that might be induced by a sudden increase in loadings.

\section{Anaerobic filter}

The anaerobic filter was inoculated with $400 \mathrm{~mL}$ of the above-mentioned inoculum, in such a way that the amount of biomass inoculated was $17.6 \mathrm{~g} \mathrm{VSS} / \mathrm{L}$. The rest of the reactor volume was charged with $950 \mathrm{~mL}$ of the above-mentioned nutrient solution composed of glucose (carbon source), ammonium chloride (nitrogen source) and potassium phosphate (phosphorus source) at a $\mathrm{C}: \mathrm{N}: \mathrm{P}$ ratio of $350: 5: 1$. The nutrients were chosen using the same criteria mentioned previously. To acclimatize the sludge to the substrate, the reactor was initially operated in batch form, with total recycling and a low superficial velocity $\left(v_{s}\right)$ of $0.1 \mathrm{~m} / \mathrm{h}$ in order to avoid drag forces that hinder the adherence of the microorganisms to the support. No standardized methodology exists to determine 
the duration of this stage, but the methodology suggested by Kobayashi et al. ${ }^{[15]}$ was followed. This method recommends measuring the biogas produced daily, and as soon as a reduction is observed, it is assumed that the nutrients have been depleted. Once this occurs, it is then possible to feed the reactor in a continuous mode. Following these criteria, the acclimatization period of the anaerobic filter lasted 30 days. During the last five days, a reduction in biogas production was observed. Therefore, on day 31 the reactor began to be fed in a continuous mode, using synthetic domestic wastewater previously hydrolyzed in the CSTR reactor as substrate. At the beginning of the study (during the first 20 days after starting-up), there was a recycling ratio of 2, with respect to the feeding flow (recirculation flow/feeding flow $=2$ ). Once the formation of a biofilm was observed, recirculation was suspended.

The methanogenic reactor operated at HRTs of 3.1, 2.4, 1.7 and $1.5 \mathrm{~h}$, the OLRs of the overall or global process being 2.05, 2.65, 3.70 and $4.30 \mathrm{~g} \mathrm{COD} / \mathrm{L} \cdot \mathrm{d}$, respectively. The samples were collected and analyzed for at least 5 consecutive days following the same procedure as that described in the CSTR reactor. The initial OLR studied for this reactor was $1 \mathrm{~g} \mathrm{COD} / \mathrm{L} \cdot \mathrm{d}$, with $v_{s}$ of $0.3 \mathrm{~m} / \mathrm{h}$, to create favorable conditions for the formation of the biofilm. Once the steady-state was achieved for each HRT studied (following the same criteria already described in the first reactor), the $v_{s}$ was increased to $0.52 \mathrm{~m} / \mathrm{h}$ according to the results obtained by Elmitwalli et al. ${ }^{[16]}$ The OLR was progressively increased once the steady-state was achieved in each case. This was carried out through increases in the feeding flow-rate, maintaining the $v_{s}$ constant, until the maximum operation value was reached. ${ }^{[14]}$

\section{RESULTS AND DISCUSSION}

\section{Hydrolytic Stage}


Table 3 shows the experimental results obtained in the hydrolytic-acidogenic stage of the two-phase anaerobic digestion process of synthetic domestic wastewater. As can be observed in this Table, the percentage of organic matter $\left(\right.$ Total $\mathrm{COD}, \mathrm{COD}_{\mathrm{T}}$ ) removed ranged between $71.0 \%$ and $59.4 \%$ when the OLR of this stage increased from 4.37 to $9.00 \mathrm{~g} \mathrm{COD} / \mathrm{L} \cdot \mathrm{d}$ and the HRT decreased from 2.7 to 1.3 h. These $\mathrm{COD}_{\mathrm{T}}$ removal efficiencies were higher than those obtained by Bouallagui et al. ${ }^{[4]}$, who obtained percentages of COD removal of between $36 \%$ and $45 \%$ treating fruit and vegetable wastes at OLR in the ranges of 3.7-10.0 $\mathrm{g} \mathrm{COD} / \mathrm{L} \cdot \mathrm{d}$ and $\mathrm{HRT}$ of 3 days, and also higher than those obtained by Blonskaja et al. ${ }^{[18]}$ processing distillery wastes, with percentages of between $35 \%$ and 54\%. This behaviour can be attributed to the fact that the two wastes mentioned in both studies are much more difficult to hydrolyze than synthetic domestic wastewater. In addition, the hydrolytic reactors used in these experiments operated at a $\mathrm{pH}$ of between 5.2 and 5.9, values for which the methanogenic microorganisms were practically inhibited and much less active than at a $\mathrm{pH}$ value of 6.5, which is the operating condition of the present study.

During the first days of operation, small amounts of biogas were produced in the hydrolytic reactor. This was probably due to the fact that a considerable population of methanogenic microorganisms were active during the start-up process. However, the methane production values began to slowly descend as these bacteria were inhibited as a result of the operating conditions established. Figure 1 shows the variation of the total $\mathrm{COD}\left(\mathrm{COD}_{\mathrm{T}}\right)$, soluble $\mathrm{COD}\left(\mathrm{COD}_{\mathrm{S}}\right)$ and particulate $\mathrm{COD}$ or fraction of COD of the suspended solids $\left(\mathrm{COD}_{\mathrm{SS}}\right)$ with OLR. As can be seen, an increase in the OLR from $4.37 \mathrm{~g}$ to $9.00 \mathrm{~g} \mathrm{COD} / \mathrm{L} \cdot \mathrm{d}$ caused an increase in the $\mathrm{COD}_{\mathrm{T}}$ and $\mathrm{COD}_{\mathrm{SS}}$, the increase being much higher in the $\mathrm{COD}_{\mathrm{SS}}$. The concentration of $\mathrm{COD}_{\mathrm{S}}$ increased more slowly than $\mathrm{COD}_{\mathrm{T}}$ and $\mathrm{COD}_{\mathrm{SS}}$ when OLR increased. Specifically, the concentration of $\mathrm{COD}_{\mathrm{SS}}$ increased slightly with OLR up to $7.9 \mathrm{~g} \mathrm{COD} / \mathrm{L} \cdot \mathrm{d}$ (equivalent to an HRT of $1.5 \mathrm{~h}$ ). For OLR values higher than $7.9 \mathrm{~g} \mathrm{COD} / \mathrm{L} \cdot \mathrm{d}$ (HTR lower than $1.5 \mathrm{~h}$ ), the effluent $\mathrm{COD}_{\mathrm{S}}$ decreased sharply, showing an inhibition of the hydrolytic stage. Therefore, according to the results obtained it can be considered that the optimum 
HRT for the hydrolytic reactor was $1.5 \mathrm{~h}(\mathrm{OLR} 7.9 \mathrm{~g} \mathrm{COD} / \mathrm{L} \cdot \mathrm{d})$. These results coincide with those obtained by Arsov et al. ${ }^{[19]}$ in a two-phase anaerobic digestion process of domestic wastewater at ambient temperature using two kinds of suspended anaerobic biomasses (floccules and granules, respectively) in the reactors and those achieved by Rincón et al. ${ }^{[20]}$ in the anaerobic acidogenic fermentation of two-phase olive mill solid residue, for which the $\mathrm{COD}_{\mathrm{S}}$ increased when OLR increased from $3.2 \mathrm{~g}$ to $12.9 \mathrm{~g} \mathrm{COD} / \mathrm{L} \cdot \mathrm{d}$ (or when HRT decreased from $50.0 \mathrm{~d}$ to $12.4 \mathrm{~d}$ ), observing a decrease in effluent $\mathrm{COD}_{\mathrm{S}}$ at OLR higher than $12.9 \mathrm{~g} \mathrm{COD} / \mathrm{L} \cdot \mathrm{d}$ (or HRT lower than $12 \mathrm{~d}$ ). In addition, Demirel and Yenigun ${ }^{[2]}$ also reported that the degree of COD solubilization and organic substrate degradation primarily depended on the HRT for other complex substrates, such as meat extract, primary sludge and municipal primary sludge-starch rich industrial wastewater, etc.

The percentage of hydrolysis can be calculated by using the equation proposed by Bouallagui et al. ${ }^{[4]}$, which measured the reduction in the COD fraction that corresponds to the suspended solids through the following expression:

$\%$ Hydrolysis $=\frac{\left(C O D_{T, I}-C O D_{S, I}\right)-\left(C O D_{T, E C S T R}-C O D_{S, E C S T R}\right)}{\left(C O D_{T, I}-C O D_{S, I}\right)} * 100$

where $C O D_{T, I}$ and $C O D_{S, I}$ correspond to the influent total and soluble COD respectively, and $C O D_{T, E} C S T R$ and $C O D_{S, E}$ CSTR correspond to the total and soluble COD of the CSTR reactor effluent, respectively.

Figure 2 shows the variation of the percentage of hydrolysis achieved in the hydrolytic reactor with operation times for the OLRs of 4.37, 5.63, 7.90 and $9.00 \mathrm{~g} \mathrm{COD} / \mathrm{L} \cdot \mathrm{d}$, which corresponded to HRTs of $2.7,2.1,1.5$ and $1.3 \mathrm{~h}$, respectively. As can be seen, the average values obtained were: $85 \%$ for OLRs of 4.37 and $7.90 \mathrm{~g} \mathrm{COD/L} \cdot \mathrm{d}$ (HRTs of 2.7 and $1.5 \mathrm{~h}$, respectively), $81 \%$ for an OLR of $5.63 \mathrm{~g}$ $\mathrm{COD} / \mathrm{L} \cdot \mathrm{d}(\mathrm{HRT}$ of $2.1 \mathrm{~h})$ and $57 \%$ for an OLR of $9.00 \mathrm{~g} \mathrm{COD} / \mathrm{L} \cdot \mathrm{d}(\mathrm{HRT}$ of $1.3 \mathrm{~h})$. These results were similar to those obtained by Bouallagui et al. ${ }^{[4]}$ in a two-phase anaerobic digestion process 
treating fruit and vegetable wastes, for which a hydrolysis percentage of $81 \%$ was achieved in the first stage at OLRs of $7.5 \mathrm{~g} \mathrm{COD} / \mathrm{L} \cdot \mathrm{d}$.

\section{Kinetics of Hydrolytic Stage}

For continuous stirred tank reactors that operate under steady-state conditions the following equation proposed by Contois ${ }^{[21]}$ can be used to determine the kinetic parameters of the process:

$H R T /\left(1+k_{d} \cdot H R T\right)=\left(B / \mu_{\max }\right)(X / S)+1 / \mu_{\max }$

where $\mu_{\max }$ is the maximum specific growth rate, $B$ is a kinetic coefficient, $H R T$ is the hydraulic retention time, $S$ is the effluent concentration in the reactor $\left(\mathrm{COD}_{\mathrm{SS}}\right), X$ is the biomass concentration and $k_{d}$ is the microbial decay coefficient.

Expression (1) is the equation of a straight line with a slope equal to $B / \mu_{\max }$ and intercept on the $y$ axis equal to $1 / \mu_{\max }$. Prior to applying this model, the value of the parameter $k_{d}$ must be calculated, for which the following equation obtained from a mass balance around the reactor can be applied:

$\left(S_{0}-S\right) /(H R T \cdot X)=\left(1 / Y_{X / S}\right)(1 / H R T)+k_{d} / Y_{X / S}$

where: $Y_{X / S}$ is the microbial yield coefficient and $S_{0}$ is the influent substrate concentration $\left(\mathrm{COD}_{\mathrm{SS}}\right)$. A plot of the first member of equation (2) versus $1 / H R T$ should be a straight line with a slope equal to $1 / Y_{X / S}$ and intercept equal to $k_{d} / Y_{X / S}$.

It is important to note that both $S_{0}$ and $S$ correspond to the influent and effluent substrate concentrations of the particulate organic matter or COD of the suspended solids ( $\left.\mathrm{COD}_{\mathrm{SS}}\right)$ respectively. Given that the anaerobic fermentation mechanism implies the need for a hydrolysis 
and solubilization of the particulate or insoluble organic matter, the kinetics of the hydrolytic stage can be studied by means of the reduction of the insoluble fraction of the organic matter present in the substrate. ${ }^{[1,20]}$

Figure 3 shows a plot of the equation (2) for the experimental data obtained in the hydrolytic stage of the present two-phase anaerobic digestion process. From this plot and using the least square method, a value of $k_{d}=3.2 \mathrm{~d}^{-1}$ was found. This value was higher than that obtained in the anaerobic acidogenesis of a synthetic wastewater based on beef extract $\left(k_{d}=1.74 \mathrm{~d}^{-1}\right)$ at mesophilic temperature $^{[22]}$ and also higher than those obtained in the anaerobic acidogenic fermentation of simple soluble substrates such as glucose, lactose, etc. $\left(k_{d}=0.1-1.5 \mathrm{~d}^{-1}\right) .{ }^{[2,23]}$ This difference in $k_{d}$ values could be attributed to the easier degradation and acidification of simple substrates based only in carbohydrates and proteins.

The kinetic parameters of the Contois equation $\left(\mu_{\max }\right.$ and $\left.B\right)$ were determined from Figure 4 by using equation (1). Their values are summarized in Table 4 . The determination coefficient obtained was very high $\left(R^{2}=0.978\right)$, which suggests that the model used fits adequately to the experimental results obtained. The value of $\mu_{\max }$ was lower than that obtained in the mesophilic $\left(35^{\circ} \mathrm{C}\right)$ anaerobic acidogenesis of synthetic wastewaters $\left(\mu_{\max }=32.6 \mathrm{~d}^{-1}\right)$ based on meat (beef) extract powder with a slightly higher influent substrate concentration $(\mathrm{COD}=2.5 \mathrm{~g} / \mathrm{L}) .{ }^{[22]} \mu_{\max }$ values reported by Demirel and Yenigun ${ }^{[2]}$ and Montalvo and Guerrero ${ }^{[23]}$ for acid-former bacteria involved in twophase anaerobic processes were found in the range of $30-65 \mathrm{~d}^{-1}$, indicating again that microbial growth on glucose, lactose and proteins was faster than that for synthetic domestic wastewater used in the present study. Ghosh ${ }^{[24]}$ also observed that the acid-formers on glucose showed a $\mu_{\max }$ value one order of magnitude larger than those achieved with sewage sludge, which can be attributed to the rate-controlling nature of the hydrolysis step for the above-mentioned substrate.

\section{Methanogenic Stage and Overall Digestion Process}


Table 5 shows the steady-state $\mathrm{COD}_{\mathrm{T}}$ and $\mathrm{COD}_{\mathrm{S}}$ values and methane production obtained for the different HRT assayed in the methanogenic stage of the two-phase anaerobic digestion process. This Table also summarizes the overall percentages of $\mathrm{COD}_{\mathrm{T}}$ degradation obtained for the different total OLR of the integral two-phase process. As can be seen, the overall $\mathrm{COD}_{\mathrm{T}}$ degradation ranged between $88.3 \%$ and $79.3 \%$ when the overall OLR increased from 2.05 to $4.3 \mathrm{~g} \mathrm{COD} / \mathrm{L} \cdot \mathrm{d}$ and the total HRT decreased from 5.8 to $2.8 \mathrm{~h}$. COD removal efficiencies of $75 \%$ were achieved in a twostage flocculent-granular sludge UASB reactor system treating domestic sewage at a temperature of $20{ }^{\circ} \mathrm{C}$ at a total HRT of $10 \mathrm{~h}(8 \mathrm{~h}$ for stage I and $2 \mathrm{~h}$ for stage 2$),{ }^{[25]}$ HRT values much higher than those used in the present work $(5.8-2.8 \mathrm{~h})$.

Figure 5 shows the comparative variation of total organic matter removal efficiency with HRT for the present two-phase anaerobic digestion process, with that obtained in the one-stage anaerobic digestion process of the same substrate. ${ }^{[14]}$ As can be observed, higher organic matter removal efficiencies were always achieved in the two-phase process for all HRTs studied. According to this plot, if a vertical straight line is drawn, for example for a HRT of $3.8 \mathrm{~h}$, removal percentages of $80 \%$ and $86 \%$ are obtained for the one-phase and two-phase processes, respectively. Apparently this increase of $6 \%$ in the biodegradation percentage would not be significant enough to implement a two-phase process. However, if the objective is a maximum reactor capacity (or minimum volume) instead of the maximum conversion for the removal percentage, for example $80 \%$, in the case of the conventional process (one-phase), a HRT of 3.8 hours is required. For a two-phase process, the HRT required is 2.9 hours. Assuming a hypothetical feeding flow of $10 \mathrm{~m}^{3} / \mathrm{d}$, a reactor volume of $38 \mathrm{~m}^{3}$ for the conventional process would be requiered and only $29 \mathrm{~m}^{3}$ for a two-phase anaerobic process, which represents a reactor volume reduction of almost $25 \%$. This reduction percentage in the reactor volume would be higher, for example, if the required biodegradation was $82 \%$. Melidis 
et al. ${ }^{[26]}$ reported reactor volume reductions of up to $40 \%$ in the two-phase anaerobic digestion process of distillery wastewater, operating at optimum temperatures in the mesophilic range. Another noteworthy aspect to be considered is the higher production of biogas obtained in the twophase process. According to the results obtained, $63 \mathrm{~mL} \mathrm{CH}_{4} / \mathrm{d}$ were produced at an OLR of $2.0 \mathrm{~g}$ $\mathrm{COD} / \mathrm{L} \cdot \mathrm{d}$, while in the conventional process (one-phase) only $32 \mathrm{~mL} \mathrm{CH}_{4} / \mathrm{d}$ were produced at the same OLR ${ }^{[14]}$, which represents an increase in the biogas production of $97 \%$ when the two-phase digestion process is used. Previous research ${ }^{[27]}$ has demonstrated that the main problem faced by the psychrophilic microflora at a low temperature is the $\mathrm{H}_{2}$ assimilation by the methanogenic microorganisms. Therefore, the improvement in the organic matter removal efficiency and biogas production of the two-phase process can be attributed to the elimination of a considerable amount of the $\mathrm{H}_{2}$ produced in the gas flow during the first stage of the process. Therefore, this considerably reduces the concentration of this compound in the hydrolytic reactor effluent that is fed later on, to the anaerobic filter, where methanegenesis takes place.

\section{CONCLUSIONS}

The results of this study demonstrate the suitability of the two-phase anaerobic digestion process for treating synthetic domestic wastewater $\left(\mathrm{COD}_{\mathrm{T}}=700 \mathrm{mg} / \mathrm{L}\right)$ at ambient temperature $\left(21-24^{\circ} \mathrm{C}\right) . \mathrm{A}$ maximum percentage of $88 \%$ of organic matter removed was achieved at a global HRT (hydrolytic + methanogenic stages) of 5.8 hours. Under these operating conditions, the production of biogas was $97 \%$ higher than that obtained in the one-phase anaerobic digestion process.

The hydrolytic activity is influenced by the HRT. A reduction in the HRT meant an increase in the amount of soluble COD in the reactor effluent. In this way, it was possible to optimize the conditions that favor the hydrolytic stage $(\mathrm{OLR}=7.9 \mathrm{~g} \mathrm{COD} / \mathrm{L} \cdot \mathrm{d}$ and $\mathrm{HRT}=1.5 \mathrm{~h})$ and, therefore, the anaerobic digestion process. 
According to the results obtained, the two-phase anaerobic digestion process is a good alternative when an improvement in the removal of organic matter and the maximization of biogas production are required. In addition, the two-phase anaerobic digestion process constitutes an excellent choice when a reduction in the overall size of the equipment is also needed.

\section{ACKNOWLEDGMENTS}

The authors wish to express their gratitude to FONDECYT project 1050320 (Chile) and Junta de Andalucia (Spain) for providing financial support.

\section{REFERENCES}

[1] Borja, R.; Sánchez, E.; Rincón, B.; Raposo, F.; Martín, M.A.; Martín, A. Study and optimization of the anaerobic acidogenic fermentation of two-phase olive pomace. Process Biochem. 2005, 40, 281-291

[2] Demirel, B.; Yenigün, O. Review: Two-phase anaerobic digestion processes: a review. J. Chem. Technol. Biotechnol. 2002, 77, 743-755.

[3] Demirel, B.; Yenigün, O. Anaerobic acidogenesis of dairy wastewater: the effects of variations in hydraulic retention time with no pH control. J. Chem. Technol. Biotechnol. 2004, 79, 755760.

[4] Bouallagui, H.; Torrijos, M., Gordon J.J.; Moletta R.; Ben Cheikh, R.; Touhami, Y.; Delgenes, J.P.; Hamdi, M. Two-phase anaerobic digestion of fruit and vegetable wastes: bioreactor performance. Biochem. Eng. J. 2004, 21, 193-197.

[5] Verrier, D.; Ray, F.; Albagnac, G. Two-phase methanization of solid vegetable wastes. Biol. Wastes, 1987, 5, 55-64. 
[6] Fang, H.H.P; Yu, H. Mesophilic acidification of gelatinaceus wastewater. J. Biotechnol. 2002, 93, 99-108.

[7] Zoetemeyer, R.J.; Van Den Heuvel, J.C.; Cohen, A. pH influence on acidogenic dissimilation of glucose in an anaerobic digester. Water Res. 1982, 16, 303-313.

[8] Elefsiniotis, P.; Oldham, W.K. Influence of $\mathrm{pH}$ on the acid-phase anaerobic digestion of primary sludge. J. Chem. Technol. Biotechnol. 1994, 60, 89-96.

[9] Horiuchi, J.I.; Shimizu, T.; Kanno, T.; Kobayashi, M. Dynamic behaviour in response to pH shift during anaerobic acidogenesis with a chenostat culture. Biotechnol. Techniques 1999, 13, 155-157.

[10] Horiuchi, J.I.; Shimizu, T.; Tada, K.; Kanno, T.; Kobayashi, M. Selective production of organic acids in anaerobic acid reactor. Bioresour. Technol. 2002, 82, 209-213.

[11] Gavala, H.N.; Angelidaki, I.; Ahring, B.K. Kinetics and modelling of anaerobic digestion process. Adv. Biochem. Eng. Biotechnol. 2003, 81, 57-93.

[12] Vavilin, V.A.; Fernández, B.; Palatsi, J.; Flotats, X. Hydrolysis kinetics in anaerobic degradation of particulate organic material: An overview. Waste Manage. 2008, 28, 939-951.

[13] Fernández, B., Poirrier, P.; Chamy, R. Effect of inoculum-substrate ratio on the start-up of solid waste anaerobic digesters. Water Sci. Technol. 2001, 44(4), 103-108.

[14] Coronado, E. Anaerobic treatment of domestic wastewater, in one-stage and two-stages, at ambient temperature. MSc Thesis, Universidad Técnica Federico Santa María, Chile, 2008.

[15] Kobayashi, H.; Stenstrom, M.K.; Mah, R.A. Treatment of low strength domestic wastewater using the anaerobic filter. Water Res. 1983, 17(8), 903-909.

[16] Elmitwalli, T.A.; Skylar, V.; Zeeman, G.; Lettinga, G. Low temperature of domestic sewage in an anaerobic hybrid or an anaerobic filter reactor. Bioresour. Technol.. 2002, 82, 233-239.

[17] APHA (American Public Health Association). Standard Methods for the Examination of Water and Wastewater. $20^{\text {th }}$ ed., APHA, Washington, DC, US, 1997. 
[18] Blonskaja, V.; Menert, A.; Vilu, R. Use of two-stage anaerobic treatment for distillery waste. Adv. Environ. Res. 2003, 7, 671-678.

[19] Arsov, R.; Ribarova, I.; Nikolov, N.; Mihailov, G. Two-phase anaerobic technology for domestic wastewater treatment at ambient temperature. Water Sci. Technol. 1999, 39(8), $115-$ 122.

[20] Rincón, B.; Sánchez, E.; Raposo, F.; Travieso, L.; Borja, A.; Martín, M.A.; Martín, A. Effect of organic loading rate of anaerobic acidogenic fermentation of two-phase olive mill solid residue. Waste Manage. 2008, 28 (5), 870-877.

[21] Hu, W.C.; Thayanithy, K.; Forster, C.F. A kinetic study of the anaerobic digestion of ice-cream wastewater. Process Biochem. 2002, 37, 965-971.

[22] Dinopoulou, G.; Sterrit, R.M.; Lester, J.N. Anaerobic acidogenesis of a complex wastewater: II. Kinetics of growth, inhibition, and product formation. Biotechnol. Bioeng. 1988, 31, 969978.

[23] Montalvo, S.; Guerrero, L. Tratamiento Anaerobio de Residuos Sólidos. Producción de Biogás. Ediciones Universidad Técnica Federico Santa María, Chile, 2003.

[24] Ghosh, S. Kinetics of acid-phase fermentation in anaerobic digestion. Biotechnol. Bioeng. 1981, 11, 301-313.

[25] Sayed, S.K.I.; Fergala, M.A.A. Two-stage UASB concept for treatment of domestic sewage including sludge stabilization. Water Sci. Technol. 1995, 32(11), 55-63.

[26] Melidis, P.; Georgiou, D.; Aivasidis, A. Scale-up and Design optimization of anaerobic immobilized cell reactors for wastewater treatment. Chem. Eng. Processing 2003, 42, 897908.

[27] Kashyap, D.R.; Dadhich, K.S.; Sharma, S.K. Biomethanation under psychrophilic conditions: a review. Bioresour. Technol. 2003, 87, 147-153. 
[28] Borja, R.; Rincón, B.; Raposo, F.; Alba, J.; Martín, A. Kinetics of mesophilic anaerobic digestion of the two-phase olive mill solid waste. Biochem. Eng. J. 2003, 15, 139-145. 
Table 1. Composition of the synthetic domestic wastewater ${ }^{[28]}$.

\begin{tabular}{|c|c|c|c|c|}
\hline \multicolumn{3}{|c|}{ Macronutrient Solution } & \multicolumn{2}{|c|}{ Micronutrient Solution } \\
\hline Compound & Source & {$[\mathrm{mg} / \mathrm{L}]$} & Compound & {$[\mathrm{mg} / \mathrm{L}]$} \\
\hline Starch & C-Carbohydrate; $80 \%$ & 200 & $\mathrm{FeCl}_{3} \cdot 4 \mathrm{H}_{2} \mathrm{O}$ & 1000 \\
\hline Ovoalbumine & C-Protein; $10 \%$ & 21.0 & $\mathrm{CoCl}_{2} \cdot 6 \mathrm{H}_{2} \mathrm{O}$ & 1000 \\
\hline Sunflower oil & C-Lipid: $10 \%$ & $13.1^{*}$ & $\mathrm{MnCl}_{2} \cdot 4 \mathrm{H}_{2} \mathrm{O}$ & 250 \\
\hline Urea & $\mathrm{N}$ & 13.0 & $\mathrm{CuCl}_{2} \cdot 2 \mathrm{H}_{2} \mathrm{O}$ & 15 \\
\hline $\mathrm{KH}_{2} \mathrm{PO}_{4}$ & $\mathrm{P}$ & 5.26 & $\mathrm{ZnCl}_{2}$ & 25 \\
\hline $\mathrm{CaCl}_{2} \cdot 2 \mathrm{H}_{2} \mathrm{O}$ & $\mathrm{Ca}$ & 22.05 & $\mathrm{H}_{3} \mathrm{BO}_{3}$ & 25 \\
\hline $\mathrm{MgSO}_{4} \cdot 7 \mathrm{H}_{2} \mathrm{O}$ & $\mathrm{Mg}$ & 0.43 & $\left(\mathrm{NH}_{4}\right)_{6} \mathrm{Mo}_{7} \mathrm{O}_{24} \cdot 4 \mathrm{H}_{2} \mathrm{O}$ & 45 \\
\hline $\mathrm{KCl}$ & K & 21.3 & $\mathrm{NaSeO}_{3} \cdot \mathrm{H}_{2} \mathrm{O}$ & 50 \\
\hline $\mathrm{NaHCO}_{3}$ & $\mathrm{Na}$ & 8.76 & $\mathrm{NiCl}_{2} \cdot 6 \mathrm{H}_{2} \mathrm{O}$ & 35 \\
\hline Yeast Extract & & 100 & EDTA & 500 \\
\hline Micronutrients & & $1.0^{*}$ & $\mathrm{HCl} 36 \%$ & $1^{*}$ \\
\hline & & & Resarzurin & 250 \\
\hline
\end{tabular}

${ }^{*}$ Amount expressed in $\mathrm{mL} / \mathrm{L}$. 
Table 2. Characteristics of the synthetic domestic wastewater used and of the real domestic wastewater reported in the literature according to the references $[15,16]$.

\begin{tabular}{ccc}
\hline Parameter & $\begin{array}{c}\text { Synthetic } \\
\text { domestic } \\
\text { wastewater * }\end{array}$ & $\begin{array}{c}\text { Real domestic } \\
\text { wastewater } \\
\text { (range of values) }\end{array}$ \\
\hline COD $_{\mathrm{T}}$ & $700(35) \mathrm{mg} / \mathrm{L}$ & $180-1100 \mathrm{mg} / \mathrm{L}$ \\
Total Suspended Solids (TSS) & $559(23) \mathrm{mg} / \mathrm{L}$ & $160-625 \mathrm{mg} / \mathrm{L}$ \\
Volatile Suspended Solids (VSS) & $520(21) \mathrm{mg} / \mathrm{L}$ & $80-580 \mathrm{mg} / \mathrm{L}$ \\
pH & $6.7(0.3)$ & $5.7-8.9$ \\
Volatile Fatty Acids (VFA) (as acetic acid) & $125(5) \mathrm{mg} / \mathrm{L}$ & $90-150 \mathrm{mg} / \mathrm{L}$ \\
Total Alkalinity & $312(15) \mathrm{mg} / \mathrm{L}$ & $190-360 \mathrm{mg} / \mathrm{L}$ \\
\hline
\end{tabular}

* Values in brackets correspond to the standard deviations of the mean values. 
Table 3. Experimental results of the hydrolytic reactor (CSTR).*

\begin{tabular}{lcccc}
\hline \multirow{2}{*}{\multicolumn{1}{c}{ Parameters }} & \multicolumn{4}{c}{ OLR $_{\mathrm{T}}(\mathrm{g} \mathrm{COD} / \mathrm{L} \cdot \mathrm{d})$} \\
\cline { 2 - 5 } & 2.05 & 2.65 & 3.70 & 4.30 \\
\hline $\mathrm{OLR}_{\mathrm{CSTR}}(\mathrm{g} \mathrm{COD} / \mathrm{L} \cdot \mathrm{d})$ & 4.37 & 5.63 & 7.90 & 9.00 \\
$\mathrm{COD}_{\mathrm{T}, \mathrm{I}}(\mathrm{mg} / \mathrm{L})$ & $636(19)$ & $655(25)$ & $639(30)$ & $637(32)$ \\
$\mathrm{COD}_{\mathrm{S}, \mathrm{I}}(\mathrm{mg} / \mathrm{L})$ & $213(12)$ & $216(11)$ & $225(12)$ & $216(11)$ \\
$\mathrm{COD}_{\mathrm{T}, \mathrm{CSTR}}(\mathrm{mg} / \mathrm{L})$ & $166(9)$ & $196(9)$ & $213(10)$ & $246(12)$ \\
$\mathrm{COD}_{\mathrm{S} \text { CSTR }}(\mathrm{mg} / \mathrm{L})$ & $124(6)$ & $132(7)$ & $137(8)$ & $67(9)$ \\
$\mathrm{pH}_{\mathrm{CSTR}}$ & 6.75 & 6.80 & 6.75 & 6.80 \\
$\mathrm{~V}_{\mathrm{CH} 4}$ ** $(\mathrm{mL} / \mathrm{d})$ & $8.6(0.5)$ & $4.7(0.3)$ & $5.8(0.3)$ & $6.2(0.4)$ \\
$\mathrm{HRT}_{\mathrm{CSTR}} * * *(\mathrm{~h})$ & 2.7 & 2.1 & 1.5 & 1.3 \\
Degradation $_{\mathrm{CSTR}}$ percentage $(\%)$ & 71.0 & 65.4 & 66.5 & 59.4 \\
\hline
\end{tabular}

* Values in brackets correspond to the standard deviations of the mean values.

$* * \mathrm{~V}_{\mathrm{CH} 4}$ : methane production.

*** HRT $_{\text {CSTR }}$ : HRT in the CSTR reactor. 
Table 4. Kinetic parameters of Contois equation.

\begin{tabular}{llll}
\hline Kinetic Eq. & $\mu_{\max }\left(\mathrm{d}^{-1}\right)$ & $B\left(\mathrm{~g} \mathrm{COD}_{\mathrm{SS}} / \mathrm{g}\right.$ VSS $)$ & $\mathrm{R}^{2}$ \\
\hline Contois & 17.6 & 0.517 & 0.978 \\
\hline
\end{tabular}


Table 5. Experimental results considering the global process.*

\begin{tabular}{lcccc}
\hline \multirow{2}{*}{\multicolumn{1}{c}{ Parameters }} & \multicolumn{4}{c}{$\mathrm{ORL}_{\mathrm{T}}(\mathrm{g} \mathrm{COD} / \mathrm{L} \cdot \mathrm{d})$} \\
\cline { 2 - 5 } & 2.05 & 2.65 & 3.70 & 4.3 \\
\hline $\mathrm{COD}_{\mathrm{T}, \mathrm{I}}(\mathrm{mg} / \mathrm{L})$ & $636(19)$ & $655(25)$ & $639(30)$ & $637(32)$ \\
$\mathrm{COD}_{\mathrm{S}, \mathrm{I}}(\mathrm{mg} / \mathrm{L})$ & $213(12)$ & $216(11)$ & $225(12)$ & $216(11)$ \\
$\mathrm{COD}_{\mathrm{T}, \mathrm{AF}}(\mathrm{mg} / \mathrm{L})^{* *}$ & $75(5)$ & $80(8)$ & $89(9)$ & $121(8)$ \\
$\mathrm{COD}_{\mathrm{S}, \mathrm{AF}}(\mathrm{mg} / \mathrm{L})^{* *}$ & $49(5)$ & $52(5)$ & $78(8)$ & $72(7)$ \\
$\mathrm{pH}_{\mathrm{AF}} * *$ & 7.12 & 7.20 & 7.10 & 7.15 \\
$\mathrm{~V}_{\mathrm{CH} 4, \mathrm{AF}}(\mathrm{mL} / \mathrm{d})^{* *}$ & $63(6)$ & $89(8)$ & ------ & ------ \\
${\mathrm{Temperature}\left({ }^{\circ} \mathrm{C}\right)}_{\mathrm{HRT}_{\mathrm{AF}}(\mathrm{h})^{* *}}$ & 22 & 22 & 23 & 23 \\
$\mathrm{HRT}_{\mathrm{Tot}}(\mathrm{h})$ & 3.1 & 2.4 & 1.7 & 1.5 \\
Degradation $_{\mathrm{Tot}}$ percentage $(\%)$ & 5.8 & 4.5 & 3.2 & 2.8 \\
\hline
\end{tabular}

* Values in brackets correspond to the standard deviations of the mean values

** AF: Anaerobic Filter.

$\mathrm{COD}_{\mathrm{T}, \mathrm{AF}}$ : total COD of the anaerobic filter effluent.

$\mathrm{COD}_{\mathrm{S}, \mathrm{AF}}$ : soluble COD of the anaerobic filter effluent.

$\mathrm{V}_{\mathrm{CH} 4, \mathrm{AF}}$ : methane production in the anaerobic filter.

$\mathrm{HRT}_{\mathrm{AF}}$ : HRT in the anaerobic filter

HRT $_{\text {Tot: }}$ total HRT (HRT of the integral two-phase anaerobic digestion process (acidogenic + methanogenic stages).

Degradation $_{\text {Tot }}$ percentage: overall percentage of $\mathrm{COD}_{\mathrm{T}}$ degradation of the two-phase anaerobic digestion process. 


\section{FIGURE CAPTIONS}

Figure 1. Effect of HRT and OLR on the effluent of the hydrolytic stage of the two-phase anaerobic digestion system.

Figure 2. Variation of the percentage of hydrolysis with time in the hydrolytic reactor (I: OLR = $4.3 \mathrm{~g} \mathrm{COD} / \mathrm{L} \cdot \mathrm{d} ; \mathrm{II}: \mathrm{OLR}=5.6 \mathrm{~g} \mathrm{COD} / \mathrm{L} \cdot \mathrm{d} ; \mathrm{III}: \mathrm{OLR}=7.9 \mathrm{~g} \mathrm{COD} / \mathrm{L} \cdot \mathrm{d} ; \mathrm{IV}: \mathrm{OLR}=9.0 \mathrm{~g}$ $\mathrm{COD} / \mathrm{L} \cdot \mathrm{d})$.

Figure 3. Determination of the kinetic parameters of equation (2) $\left(k_{d}\right)$.

Figure 4. Determination of the kinetic parameters of equation (1).

Figure 5. Comparison of the variation of organic matter removal efficiencies with HRT in the onephase and two-phase anaerobic digestion processes. 


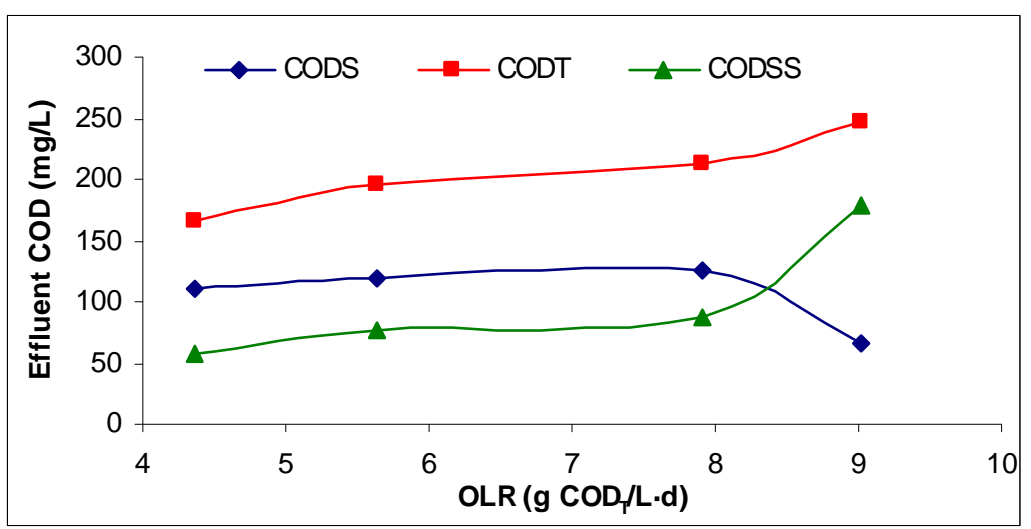

Fig. 1 


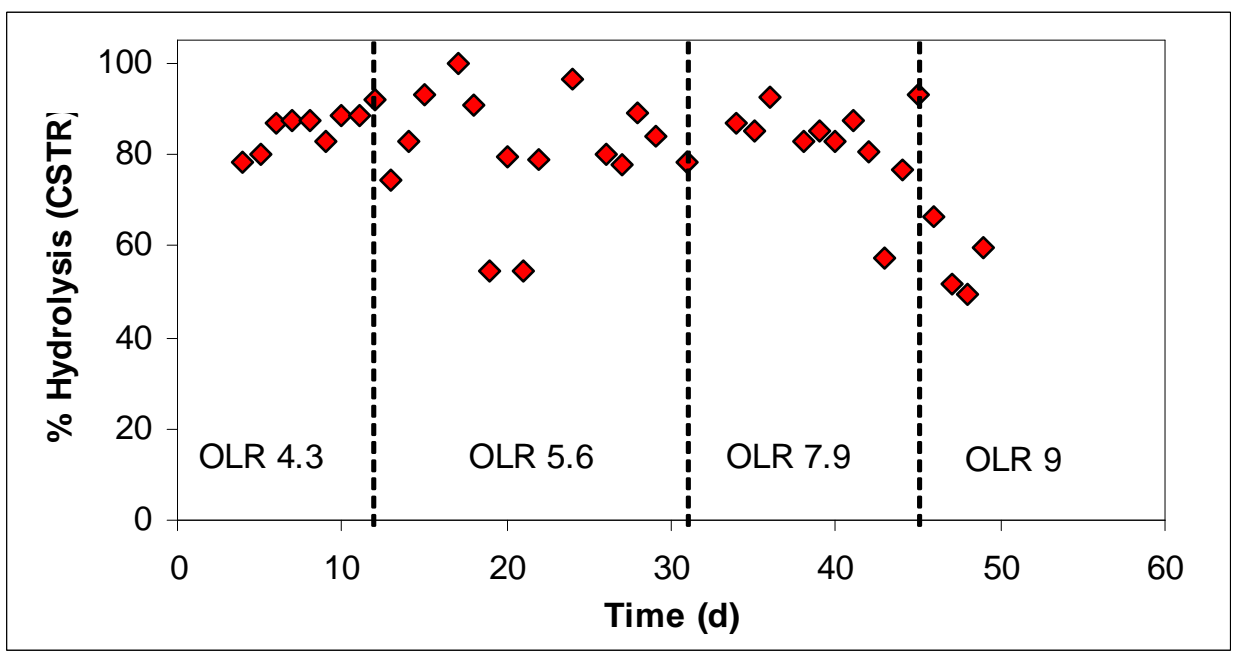

Fig. 2 


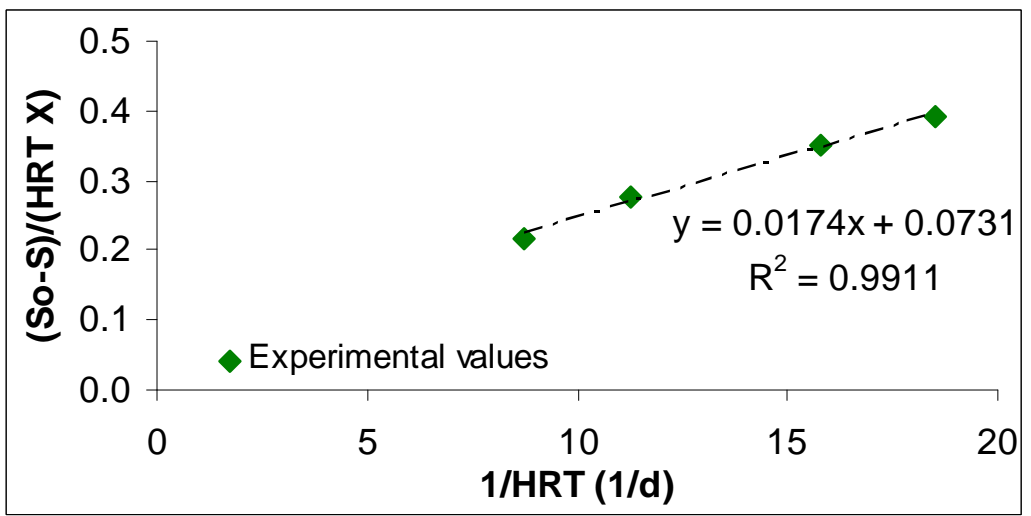

Fig. 3 


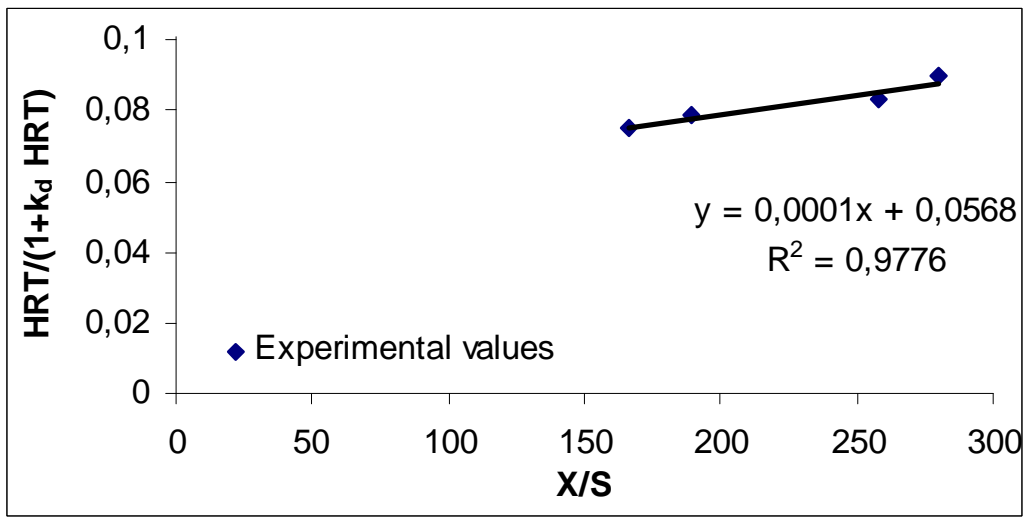

Fig. 4 


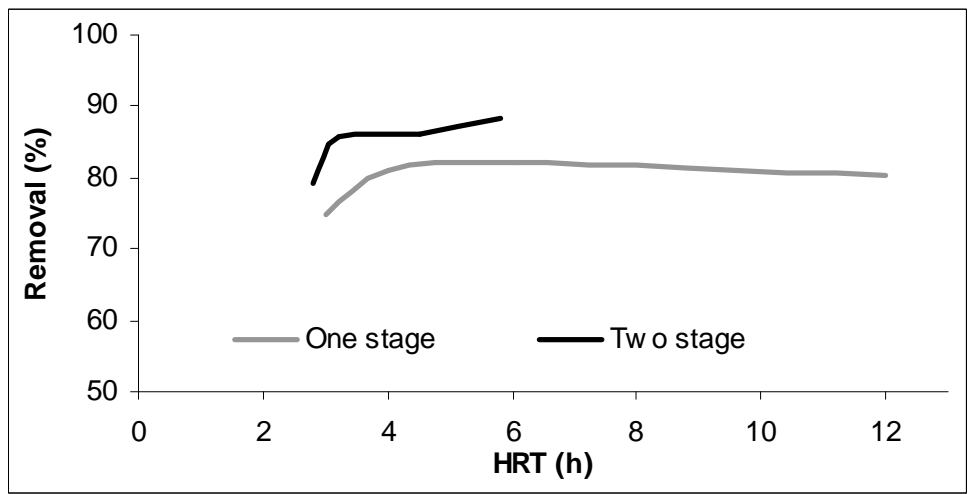

Fig. 5 